\title{
SMRT A ČAS Poslední přednášky Emmanuela Levinase
}

Ve svém posledním roce v pozici řádného profesora na Sorbonně vypsal Levinas přednášky s titulem La Mort et le Temps. Akademický rok 1975-1976 byl pro smrt ve filosofii vůbec dobrým ročníkem. Jen o pár ulic dále, na École Normale Supérieure, pořádal Derrida celoroční seminář La vie la mort. ${ }^{1}$ Vyšel první a nejvýznamnější z řady krátkých textů, které ve stáří věnoval smrti a pomíjivosti Gadamer. ${ }^{2}$ A na konci letního semestru ve Freiburgu zemřel Martin Heidegger.

V sorbonnských přednáškách, které skončily jen o necelý týden dříve, podal Levinas svi̊j nejobsáhlejší výklad o smrti a zároveň přehlédl celou svou dosavadní filosofickou dráhu. Vyšel ze svého velkého pozdního díla Autrement qu'être ${ }^{3}$ které bylo publikováno krátce předtím, a vrátil se až $\mathrm{k}$ vlastnímu filosofickému průlomu ve druhé polovině čtyřicátých let. ${ }^{4}$ Ze své pozdní pozice tak hájil tezi, kterou přednesl již v knize Existence a ten, $k$ do existuje: čas, jenž každý z nás prožívá, je naším vztahem k druhým lidem. Stejně jako v Čase a Jiném se přitom pokusil demonstrovat, jakou roli v našem vztahu k druhým hraje smrt a jak smrtelnost spoluurčuje naše prožívání času.

Přednášky o smrti a čase vyšly až krátce před Levinasovou vlastní smrtí, nejprve samostatně a poté - spolu s paralelním cyklem ze stejného roku a na neméně ultimátní téma - v knize Dieu, la Mort et le Temps..$^{5}$ Jako učitel a spisovatel se Levinas údajně řídil dvěma maxi-

\footnotetext{
1 J. Derrida, La vie la mort. Séminaire (1975-1976), Paris 2019.

2 H.-G. Gadamer, Der Tod als Frage, in: týž, Neuere Philosophie, II, Probleme, Gestalten, Tübingen 1987, str. 161-172.

3 E. Levinas, Autrement qu'être ou au-delà de l'essence, Paris 1974.

$4 \quad$ V letech 1947-1949 vyšly Levinasovy knihy De l'existence à l'existant (Existence a ten, kdo existuje, přel. P. Daniš, Praha 2009), Le Temps et l'Autre (Čas a Jiné, přel. Z. Hrbata, Praha 1997) a En découvrant l'existence avec Husserl et Heidegger (Objevování existence s Husserlem a Heideggerem, přel. J. Bierhanzl - J. Fulka K. Novotný, Červený Kostelec 2014).

5 E. Levinas, Dieu, la Mort et le Temps, Paris 1993. Na YouTube je možné pod titulem Interview with Levinas najít televizní rozhovor, ve kterém starý Levinas svou novou knížku propaguje. Cyklus La Mort et le Temps vyšel poprvé v Cahiers de L'Herne, 60, 1991.
} 
mami. ${ }^{6}$ Ve svých universitních kursech se soustředil na výklad dějin filosofie, vlastní filosofické úvahy si schovával pro své knihy. V těch se pak nepouštěl do dlouhých dialogů s ostatními autory, pokud jim tu či onu knihu př́imo nevěnoval. Svými posledními přednáškami a jejich následným vydáním porušil obě tyto maximy.

Jak prozrazuje již samotný titul, přednášky postupují ve směru od smrti k času. Činí tak ve třech hlavních krocích. V úvodní části cyklu, které byly věnovány první tři hodiny, se Levinas pouští do fenomenologie smrti. Při svých analýzách si zároveň připravuje argumentační a pojmovou munici pro následnou polemiku se svými předchůdci. Té je poté věnována nejobsáhlejší a také nejvíce školská část přednášek, která pokryla většinu akademického roku. Tato polemika je ostrá v př́ípadě filosofü, které Levinas počítá mezi své protivníky, a přátelská v př́ípadě těch, které řadí mezi své spojence. Protivníky spatřuje v těch autorech, kteří problém smrti chápou jako problém vztahu mezi bytím a nebytím, resp. nicotou. Takovýto ontologický pojem smrti nachází především u Hegela a pochopitelně u Heideggera. Spojenci mu jsou naopak ti autoři, kteří problém smrti chápou jakožto problém jednání. Etický a humanistický pojem smrti nachází Levinas především v Kantově praktické filosofii a v díle Ernsta Blocha. V závěrečné části cyklu, které zůstaly vyhrazeny poslední tři hodiny letního semestru, pak na řadu přichází Levinasův výklad času. Jeho východiskem je přitom Blochem inspirovaná a proti Heideggerovi namířená teze, která celý dosavadní postup přednášek obrací naruby: o smrti je nutné přemýšlet na základě předem zformulovaného pojmu času - a nikoli naopak, na základě předem zformulovaného pojmu smrti přemýšlet o čase. Pojem času, kterým celý cyklus vrcholí, je proto avizován již na úvod první hodiny a leží v pozadí všech následujících fenomenologických analýz a historických exkursů. Formulován je, většinou explicitně, vůči ranému Heideggerovi a, většinou implicitně, vůči Husserlovi.

Je-li podle Heideggera původní čas mým vztahem k sobě samému, je podle Levinase mým vztahem k druhým. Podle Heideggera je čas horizontem, v němž rozumím svému bytí ve světě. Sám sobě rozumím z budoucnosti, ze svých možností, z nichž rozvrhuji smysl své existence. V možnostech, kterých se chápu, i v těch, které jsou mi odepřeny, jsem zároveň konfrontován se svou minulostí či bývalostí, která na mne z mých možností padá v podobě mé nálady. V náladě, která mne napl ňuje, a ve světle možností, z nichž si rozumím, se mne pak týká a svůj význam pro

6 Tuto informaci se dovídáme od vydavatele Levinasových přednášek: J. Rolland, Avertissement, in: E. Levinas, Dieu, la Mort et le Temps, str. 9-10. 
mne nabývá vše, co je mi ve světě přítomné: „věci““ a druzí. Vždy si přitom rozumím - at' již zastřeně, anebo průhledně - z možnosti vlastní smrti, ve které jsem konfrontován s faktem, že vůbec jsem - a že jsoucí vůbec je.

Čas, který je podle Levinase mým vztahem k druhým, oproti tomu můj vztah k sobě samému překračuje. Druzí mi nikdy nejsou ve světě prrítomni ve své niternosti; ta se ve světě pouze projevuje v jejich tváŕích. Protože jejich nitro a záměry mi zůstávají skryty, jsou pro mě druzí vždy situováni mimo mé možnosti a má očekávání. Přesto mne k nim již od mého narození vážou pouta, která předcházejí veškeré mé osobní historii a teprve mne jakožto jednotlivou osobu definují.

Je-li proto podle Husserla původní čas syntetickou aktivitou mé subjektivity, je podle Levinase její pasivitou. Podle Husserla je základní zkušeností - prafenoménem - času jeho plynutí. Zkušenost plynutí času mi zprostředkovává asociativní syntéza, jež spojuje mé přítomné imprese s mou minulou zkušeností, kterou si podržuji v paměti. Má minulá zkušenost pak asociativně předznačuje možný průběh mé budoucí zkušenosti, kterou očekávám. V syntéze impresí, retencí a protencí se tak má subjektivita sama konstituuje jako prožitkový proud.

Čas, který je pasivitou mé subjektivity, je oproti tomu afektivitou, která mne otevírá druhým, a emocionalitou, která mne k druhým poutá. Moje Já samo je ve své jednotlivosti podle Levinase konstituováno city, které ve mně druzí jednotlivci probouzejí a které mne k nim poutají. Má citová pouta $\mathrm{k}$ druhým proto sahají hlouběji do mé minulosti než má pamět'. Mé city přitom směřují k nitru druhých, jež mé vlastní subjektivitě zůstává uzavřeno. Druzí mne tak k sobě poutají ve své neuchopitelnosti, díky níž se vymykají mým očekáváním. Časový smysl tohoto pouta uchopuje Levinas v bergsonovském pojmu trvání, kterému však dává nový význam. Trvání času, jež prožívám ve svých citech vůči druhým, je mou trpělivostí, již chovám vůči těm, kteří mi nikdy nejsou lhostejní a zároveň jsou pro mne vždy nepředvídatelní.

Na základě tohoto pojmu času přemýšlí Levinas o smrti. Vychází přitom - opět v opozici vůči Heideggerovi, ale také vůči vlastním raným úvahám ${ }^{7}-$ z události smrti druhého a blízkého člověka. Smrt druhého je podle Levinase událostí, která se vzpírá veškeré mé zkušenosti. Smrt druhého mne konfrontuje s odchodem druhého ze světa, v němž se druhý již nikdy neprojeví; jeho tělo se stalo bezvládným a jeho tváŕ znehybněla. Co se však s druhým ve smrti stalo, to nevím a ani vědět nemohu, protože vlastní smrt jsem nezažil. Smrt pro mne zůstává záhadou, jež ve

7 Srv. E. Levinas, Čas a Jiné, str. 92-127 (kapitola 3). 
mně vyvolává dvojznačné pocity. Smrt druhého ve mně probouzí hrůzu z toho, že druhý mne navždy nechal ve světě opuštěného, a zároveň pocit viny, že jsem jeho odchodu nedokázal zabránit, či si jej dokonce přál. Má vlastní smrt, jež na mne čeká, mne na jednu stranu naplňuje heideggerovskou úzkostí z nicoty, na druhou ale také nadějí, která se upíná za tento svět.

Smrt, jež se vzpírá světské zkušenosti, pak nachází svou světskou instanci ve tvářích druhých. Druzí se na mne obrací ve své smrtelnosti a zranitelnosti - a ve své smrtelnosti a zranitelnosti mne také zavazují. Citová pouta, která mne s nimi pojí, jsou tudíž vždy pouty zodpovědnosti. V zodpovědnosti, kterou ve mně druzí probouzejí, také nabývá svůj plný smysl trpělivost, kterou vůči druhým chovám. Smrtelnost totiž nikdy nedokážu z druhých sejmout a sám jednoho dne také zemřu.

Mé dny proto neplynou pouze v mých plánech a očekáváních, v nichž se vyrovnávám se svou minulostí, nýbrž můj život především trvá ve dvojím trpělivém čekání: v čekání na druhé, kteří se mým očekáváním vymykají svou nepředvídatelností a kteří mne zavazují svou zranitelností; a v čekání na mou smrt, která se mým očekáváním vymyká, protože neznám okamžik jejího příchodu. Druzí dávají nakonec všem mým plánům a očekáváním jejich smysl, příchod mé smrti všem mým plánům a očekáváním nakonec jejich smysl bere. Čas sám je vztahem smrtelníka k druhým smrtelníkům.

O smrti a čase Levinas přednášel každý týden pouze hodinu (vždy v pátek ráno od deseti do jedenácti hodin), v průběhu svého posledního vyučovacího roku oslavil sedmdesátiny a podle pamětníků nikdy nevynikal živým přednesem. Svým sorbonnským studentům musel přesto sdělit více, než se lze dočíst z kusých a úsečně formulovaných manuskriptů. Ty tak téměř k dokonalosti dovádí styl autora, jenž si vždy liboval v hyperbolických formulacích a vždy šetřil argumentací. Své nestravitelnosti navzdory se však text stal klasickým záhy po svém vydání. Na začátku devadesátých let mu totiž věnoval komentář Derrida ve své knize Donner la mort $^{8}{ }^{8} \mathrm{v}$ té knize, která zároveň proslavila po celém světě dílo Jana Patočky. ${ }^{9}$

Ondřej Kvapil

8 J. Derrida, Donner la mort, Paris 1999. Česky vyšly první dvě kapitoly, které Derrida odpřednášel v Praze: J. Derrida, Tajemství, kacířství a odpovědnost. Patočkova Evropa, přel. M. Petříček, in: Filosofický časopis, 4-5, 1992, str. 551-573 a 857-867.

9 Text vznikl v rámci zastřešujícího projektu Kontinuita a diskontinuita ve filosofii, literatuře a umění řešeného na Filozofické fakultě Univerzity Karlovy z prostředků Specifického vysokoškolského výzkumu na rok 2020. 